\title{
ECOLOGY
}

DOI https://doi.org/10.30525/978-9934-26-111-4-9

\section{УШКОДЖЕННЯ ТВЕРДОГО ТІЛА ДВОСТУЛКОВИХ МОЛЮСКІВ РОДИНИ КУЛЬКОВИХ (МОLLUSCA: BIVALVIA: PISIDIDAE) ЯК РЕЗУЛЬТАТ НЕГАТИВНОГО ВПЛИВУ НАВКОЛИШНЬОГО СЕРЕДОВИЩА}

\author{
Билина Л. В. \\ аспірант \\ Житомирський державний університет імені Івана Франка \\ Шевчук Л. М. \\ доктор біологічних наук, професор \\ Житомирський державний університет імені Івана Франка \\ м. Житомир, Украӥна
}

Зростання антропогенного впливу на прісноводні гідро екосистеми позначаються не лише на якісному та кількісному складі зооценозів, а на особливостях процесів життєдіяльності гідробіонтів. Серед прісноводних двостулкових молюсків, представлених на території України, слід відмітити перлівницевих (Unionidae) та кулькових (Pisididae). Вони є природними фільтраторами водних об'єктів. Ці молюски живляться частинками органічних речовин, дрібним планктоном і тому відіграють істотну роль у біологічному очищенні вод [2]. Перлівницеві - це найбільші двостулкові м'якуни водойм та водотоків України, кулькові - найдрібніші представники двостулкових молюсків, які зараз є малочисельними. Чіткої думки щодо кількості видів кулькових в Україні не існує, за різними таксономічними підходами їх вказують від 16 до 74 видів [2,3,4,5]. Молюски родини Pisidiidae в Україні, за літературними даними [4], представлені трьома родами: Sphaerium, Musculium, Pisidium (Euglesa). Зрозуміло, що при погіршенні екологічного стану водойм, неможливо не замислюватись над питаннями умов існування гідробіонтів, їх чисельності, щільності поселень, різноманіття видового складу поселень.

Метою даної роботи було з'ясування видового різноманіття кулькових Житомирського Полісся та вивчення травматичної мінливості твердого тіла (черепашки), яке найбільше контактує із зміненим середовищем існування. До травматичної мінливості двостулкових молюсків можна віднести випадки прижиттєвої корозії 
черепашки, зміну іï первинного кольору, які викликаються особливостями хімічного складу водного середовища [1], а також забрудненням води, утворення скульптурних пустотілих розростань (здуття) внутрішнього шару черепашки (гіпоостракуму), спричинених зростанням каламутності води i, як наслідок, подразненням тіла дисперсними частинками, а також деформування черепашки, спричинені механічними впливами. Усі ці зміни були відмічені нами у перлівницевих, які мають більшу, ніж кулькові тривалість життя, й, тому, більшу ймовірність зазнати впливу забрудненого середовища.

Матеріалом даної роботи слугували кулькові родів: Sphaerium, Pisidium (Euglesa), зібрані протягом 2019-2020 pp. на території Житомирської області.

Загалом обстежено 1240 екземплярів черепашок семи видів кулькових, а саме: Sp. corneum Linnaeus, 1758, Sp. solidum Normand, 1844, Sp. rivicola Lamarck, 1818, Sp. nitidum Clessin, 1876, Sp. nucleus Studer, 1820, P. amnicum Muller, 1774, P. supinum Schmidt, 1851. Досліджених представників було зібрано із 21 пункта у межах Житомирської області, розташованих у 2 річкових басейнах. Інформацію про матеріал дослідження наведено у таблиці 1.

Таблиця 1

Пошкодження твердого тіла молюсків сучасних водойм та водотоків Житомирської області

\begin{tabular}{|c|c|c|c|c|}
\hline \multirow[b]{2}{*}{$\begin{array}{c}\text { Вид } \\
\text { молюска }\end{array}$} & \multirow[b]{2}{*}{$\begin{array}{c}\text { Кількість } \\
\text { досліджених } \\
\text { особин, екз }\end{array}$} & \multicolumn{3}{|c|}{ Аномалії в будові черепашки } \\
\hline & & $\begin{array}{c}\text { Скульптурні } \\
\text { утворення } \\
\text { гіпоостракуму, } \\
\text { екз (\%) }\end{array}$ & $\begin{array}{c}\text { Деформачія } \\
\text { черепашки, } \\
\text { екз (\%) }\end{array}$ & $\begin{array}{c}\text { Зміна } \\
\text { первинного } \\
\text { кольору } \\
\text { гіпоостракуму, } \\
\text { екз (\%) }\end{array}$ \\
\hline Sp.rivicola & 759 & - & $128(17)$ & - \\
\hline $\begin{array}{c}\text { Sp. } \\
\text { nucleus }\end{array}$ & 308 & - & $16(5)$ & - \\
\hline $\begin{array}{c}P . \\
\text { amnicum }\end{array}$ & 40 & - & $1(2,5 \%)$ & - \\
\hline $\begin{array}{c}\text { Sp. } \\
\text { corneum }\end{array}$ & 22 & - & - & - \\
\hline $\begin{array}{c}\text { Sp. } \\
\text { solidum }\end{array}$ & 22 & - & - & - \\
\hline $\begin{array}{c}\text { Sp. } \\
\text { nitidum }\end{array}$ & 61 & - & - & - \\
\hline $\begin{array}{c}P . \\
\text { supinum }\end{array}$ & 28 & - & - & - \\
\hline
\end{tabular}


Збір, транспортування та утримання кулькових здійснювався згідно загальноприйнятих методик [4]. Також обстежено черепашки 262 екземплярів молюсків родини Sphaerium, Pisidium (Euglesa) Державного природознавчого музею НАН України (м. Київ та м. Львів). Для аналізу відібрано матеріал, який було зібрано до 1914 року, тобто до значних зрушень у гідроценозах. У ході дослідження використовувався метод визначення виду досліджуваних тварин, а також візуального обстеження черепашок молюсків з метою виявлення каліцтва та аномалій. Корозію черепашки внаслідок впливу ph середовища, що спостерігається в нормі у водоймах півночі Поліського регіону ми не аналізували.

Аналіз травматичної мінливості твердого тіла кулькових показав, що травматичний характер проявлявся тільки механічним пошкодженням (деформацією) черепашки (рис.1), зміни первинного кольору та скульптурні утворення гіпоостракуму не спостерігалося.
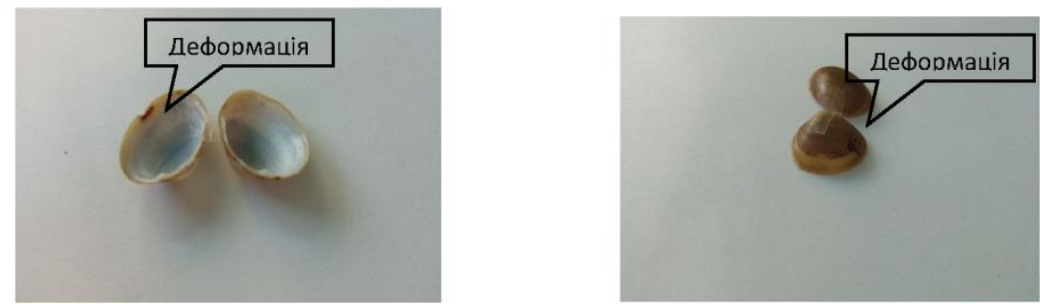

Рис. 1 Пошкодження черепашки Sp. rivicola із річки Гнилоп'ятка

Для перевірки цих даних, ми також проаналізували малакологічні колекції молюсків родів: Sphaerium, Pisidium (Euglesa) та Musculium Державного природознавчого музею НАН України (м. Київ та м. Львів). Для аналізу було відібрано матеріал, зібраний до 1914 року. Візуальне обстеження черепашок дозволило встановити, що кулькові 3 музейних колекцій також мали лише механічні пошкодження черепашки, а зміни первинного кольору та скульптурні утворення гіпоостракуму також не були виявлені. Загалом відсоток особин 3 деформацією черепашки у мізейних колекціях не перевищував $5 \%$.

Отже, загалом при обстеженні Sp. rivicola механічні ушкодження черепашки мали 128 тварин із 759 обстежених, що становить $17 \%$ та 16 екземплярів Sp. nucleus iз 308 обстежених, що становить 5\%. При обстеженні P. amnicum було виявлено тільки 1 незначну деформацію 
черепашки із 40 досліджених тварин, що становить 2,5\%. Ушкодження черепашки реєструвалось тільки в дорослих особин, тобто не $є$ вродженими, а виникає на певних стадіях індивідуального розвитку під дією чинників середовища.

Таблиця 2

Пошкодження твердого тіла молюсків конкретних пунктів збору водойм та водотоків Житомирської області

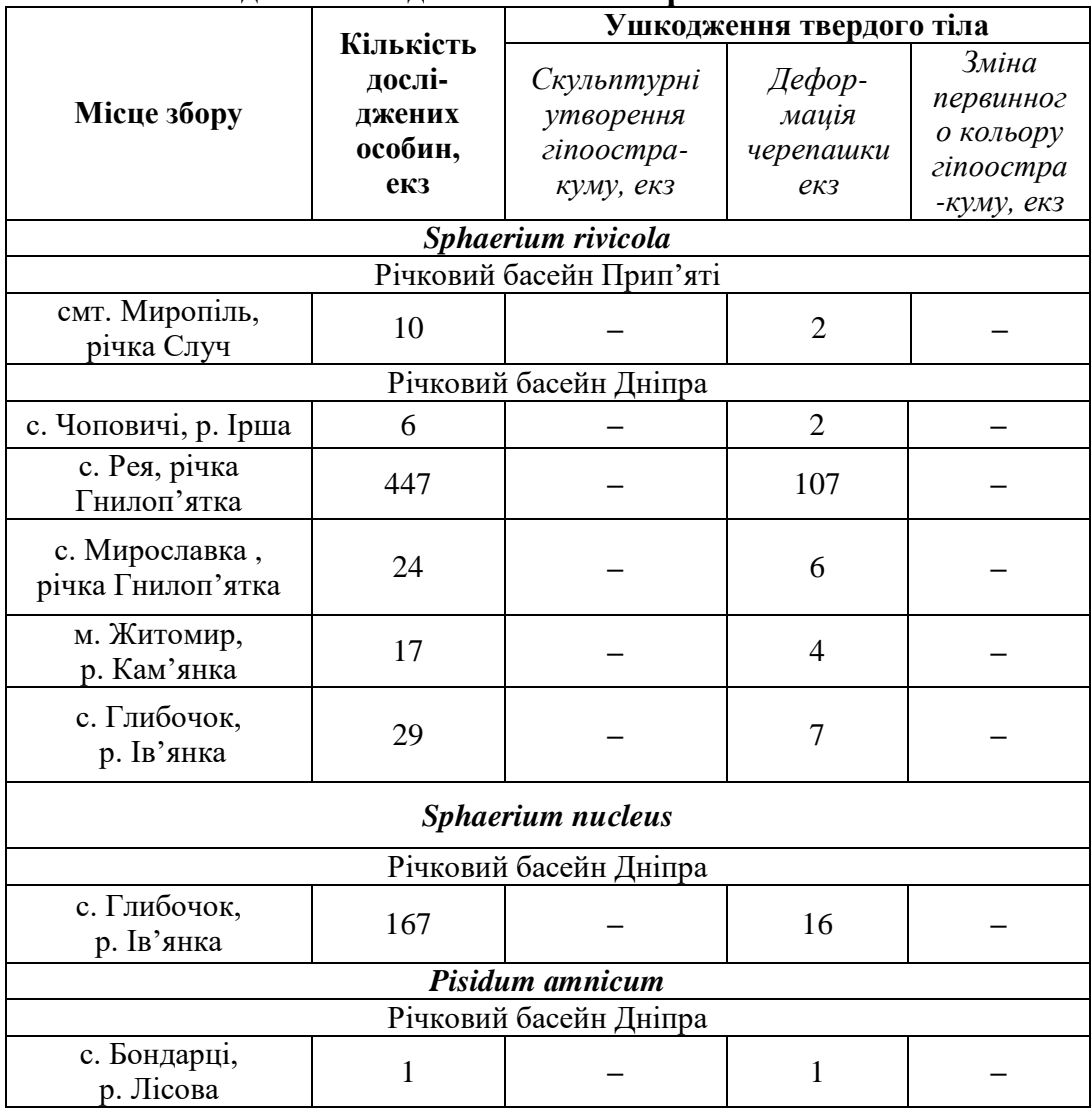

\section{Література:}

1. Гідрохімія та радіогеохімія річок і боліт Житомирської області: Монографія / С.І. Сніжко, О.О. Орлов, Д.В. Закревський та ін. Житомир: Волинь, 2002. 264 с. 
2. Жадин В.И. Моллюски пресных и солоноватых вод СССР. Москва - Ленинград : изд-во АН СССР. 1952. 376 с.

3. Korniushin A.V., Yanovich L.N., Melnichenko R.K. Artenliste der Süfswassermuscheln der Ukraine. Mit Bemerkungen über taxonomischen Status, Verbreitung und Gefährdungskategorien einiger Arten und Formen. ConchBooks : Friedrich-HeldGesellschaft, 2002. S. 463-478.

4. Стадниченко А. П. Фауна України. Перлівницеві. Кулькові (Unionidae, Cycladidae). К. :Наук. думка, 1984. Т. 29. Вип. 9. 384c.

5. Piechocki A. Dyduch-Falniowska A. Mięczaki (Mollusca), małże (Bivalvia). Fauna słodkowodna Polski, z. 7A. Wydawnictwo Naukowe PWN, Warszawa, 1993. 202 pp.

DOI https://doi.org/10.30525/978-9934-26-111-4-10

\title{
ЕКОЛОГІЧНІ ПРОБЛЕМИ ТИЛІГУЛЬСЬКОГО ЛИМАНУ
}

\author{
Бургаз М. I. \\ кандидат біологічних наук, \\ дочент кафедри водних біоресурсів та аквакультури \\ Одеський державний екологічний університет \\ Шекк П. В. \\ доктор сільськогосподарських наук, професор, \\ завідувач кафедри водних біоресурсів та аквакультури \\ Одеський державний екологічний університет
}

Лічна А. I.

асистент кафедри водних біоресурсів та аквакультури

Одеський державний екологічний університет

м. Одеса, Україна

Тилігульський лиман розташований в 40 км від м. Одеси на кордоні Одеської та Миколаївської областей. Лиман уявляє собою затоплену морськими водами долину річки Тилігул. Лиман відокремлений від моря природним піщано-черепашковим пересипом шириною від 3,3 до 4,0 км і довжиною до 6,6 км. Формування пересипу відбулося наприкінці XVIII - на початку XIX сторіч. Нині пересип $\epsilon$

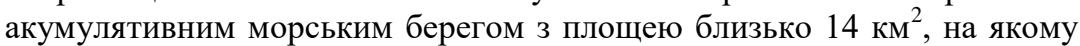
відкладається 70 тис. м $^{3}$ наносів на рік [1]. 